المفاضلة بين الرواة بلفظ "فلان أحبُّ إليّّ" عند نقاد الحديث

\title{
Hadis Münekkidleri Tarafından Râviler Arasında "Bana Daha Sevimli" Lafzıyla Tercih Yapılması
}

\section{The Preference in Between of the Narrators with the State of "He Is More Loved to Me" By the Hadith Critics}

\author{
Mohamad Anas SARMINI \\ Dr. Öğr. Üyesi, İstanbul 29 Mayıs Üniversitesi, Illahiyat Fakültesi, Hadis Anabilim Dalı \\ Assistant Professor Istanbul 29 May University, Faculty of Theology, Department of Hadith \\ Ümraniye/Istanbul, Turkey \\ asarmini@29mayis.edu.tr \\ orcid.org/0000-0002-6396-374X
}

\author{
Makale Bilgisi / Article Information \\ Makale Türü / Article Types : Araştırma Makalesi / Research Article \\ Geliş Tarihi / Received : : : 19 Eylül / September 2019 \\ Kabul Tarihi / Accepted : : 3 Aralık / December 2019 \\ Yayın Tarihi / Published $\quad$ : 15 Aralık / December 2019 \\ Yayın Sezonu / Pub Date Season : Aralık / December \\ Cilt / Volume: 6 - Sayı / Issue: 2 - Sayfa / Pages: $367-384$ \\ Atıf / Cite as \\ Sarmini, Mohamad Anas. Bülent Ecevit Üniversitesi Illahiyat \\ Fakültesi Dergisi,"6/2 (2019): 367-384 \\ Doi: $10.33460 /$ beuifd.622369 \\ İntihal / Plagiarism \\ Bu makale, en az iki hakem tarafından incelendi ve intihal olmadığı teyit edildi. \\ This article has been reviewed by at least two referees and scanned via a plagiarism software. \\ Yayın Hakkı / Copyright ${ }^{\circ}$ \\ Zonguldak Bülent Ecevit Üniversitesi, İlahiyat Fakültesi tarafından yayınlanmıștır. Tüm hakları saklıdır. \\ Published by Zonguldak Bulent Ecevit University, Faculty of Theology, Zonguldak, Turkey. All rights reserved.
}

الملخص

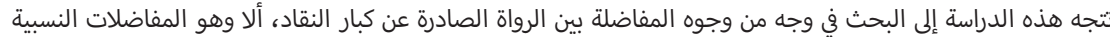

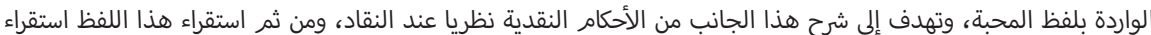

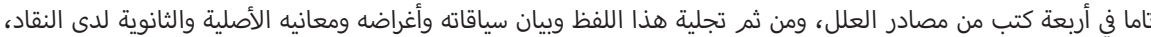

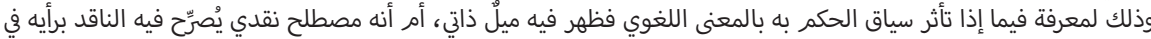

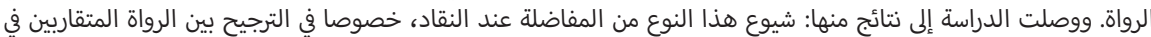

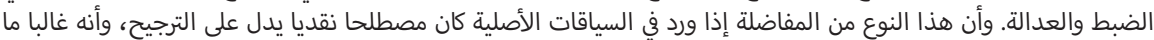

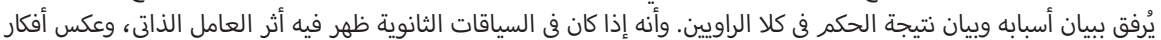
الناقد واختياراته الذاتية.

الكلمات المفتاحية: الحديث, المفاضلة, نقد الرواة, أحب إليَّ, علل الحديث, الرواة المتقاربون 
Öz: Bu çalışma önde gelen münekkidler tarafından ortaya konulan, raviler arasındaki tercih yönlerinden birini; "sevgi" kelimesi kullanılarak yapılmış kısmî tercih yönünü araştırmaya yöneliktir. Çalışma münekkidler nezdindeki tenkid kurallarının bu yönünü açıklamayı hedeflemektedir. Çalışmada öncelikle ilelü'l-hadîs türü eserlerin dördünde bu kelime ayrıntılı bir şekilde incelenecektir. Daha sonra eleştirmenler için bu kelimenin yansımaları, kullanıldığı bağlamlar, kullanılma amaçları, aslî ve yan anlamları incelenecektir. Bu incelemenin amacı hadis hakkında verilen hükmün, bu kelimenin sözlük anlamından etkilenip bunun sonucunda tamamen şahsi bir meyille mi verildiğinin yoksa bu kelimenin münekkidin ravi hakkındaki görüşünü açıkladığı bir tenkid kavramı mı olduğunun anlaşılmasıdır. Çalışmada üç temel sonuca ulaşılmıştır. Bunlardan ilki, bu tercih kriterinin özellikle adalet ve zabt bakımından birbirine yakın olan raviler arasında tercih yapılırken kullanıldığının tespit edilmesidir. Bir diğer sonuç kelime, aslî anlamında kullanıldığında tercihe delalet eden bir tenkid terimi olarak kullanılmışır. Genellikle tercihle beraber bunun sebebi ve iki râviden her birinin tercih edilmesi durumunda doğacak sonuç da zikredilmiştir. Son olarak bu kelimenin münekkidler tarafından yan anlamlarda da kullanıldığı ve bu yolla münekkidlerin tercihlerini, fikirlerini ve seçimlerini yansıttığı görülmüştür.

Anahtar Kelimeler: Hadis, Tercih, Râvi Tenkidi, Bana Daha Sevimli, Ilelü'l-Hadîs, Birbirine Yakın Râvileri

Abstract: This paper aims at study one aspect of the preference among the narrators by the critics. It is the words of "he is more loved to me" which is one of the relative preferences. It aims to explain this aspect of critical judgments theoretically in the critics, and then extrapolate this term fully in four books of sources of Ilalu Hadith. This term has lingual connotation and terminological connotation. Critics usually use this term for its terminological connotation. This paper aims to make sure if the critics used this term in some contexts in the lingual connotation which implies to the sense of tendency towards people of issues.

The study reached some results, the prevalence of this type of the preference with critics, especially in the weighting between the narrators who are similar to each other in credibility and justice. This type of preference, if it is given in the original contexts, is a terminological judgment for weighting between narrators, especially when it is accompanied by a statement of its reasons and the outcome of the judgment in both narrators, and if it is given in the secondary contexts, it can be noticed the effect of selftendency, and reflected the critic personal opinions and his own choices.

Key Words: Hadith, Preference, Critique of Narrators, More Loved to Me, Ilalu Hadith, Similar Narrators 
الحمد لله رب العالمين وأفضل الصلاة وأتم التسليم على سيدنا محمد وعلى آله وصحبه أجمعين، وبعد، فإن وجوه المفاصلة

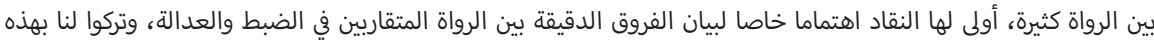

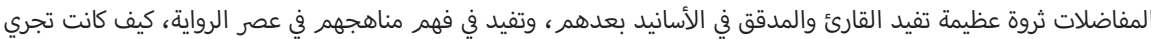
الترجيحات بين الروايات والرواة، وأثر ذلك في التصحيح والتضعيف والعمل، وإن ومن هنا تأتي أهمية هذه الدراسة وكل دراسة في هذا

الميدان.

على أن الدراسات التي تناولت ألفاظ المفاضلة بين الرواة قد تعددت مؤخرا، إذ يأتي في مقدمتها كتاب الدكتور محمد خروبات:

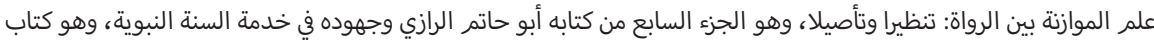

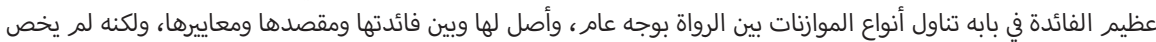

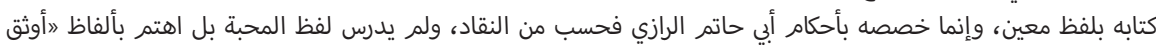

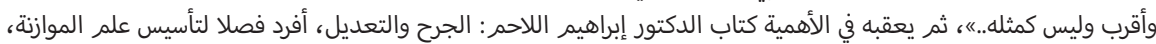

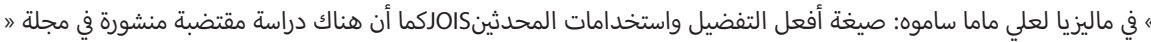

لها في توثيق الرواة.

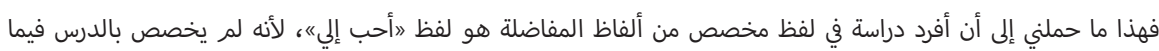

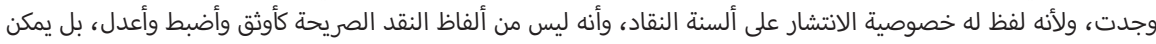

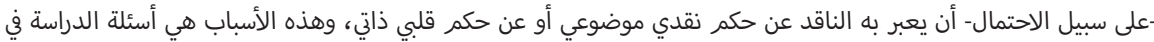

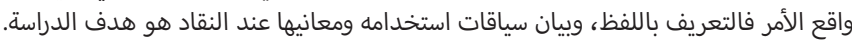

ولقد حددت البحث باللفظ المذكور فقط، وحددت مصادره بأربعة كتب هي علل أحمد وعلل أبي حاتم وضعفاء العقيلي وعلل

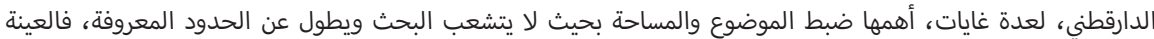

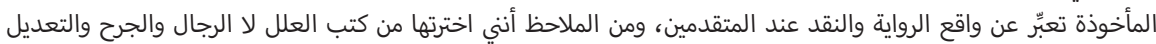

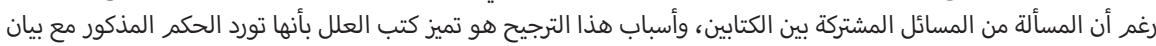

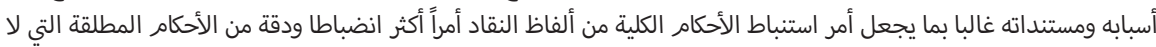

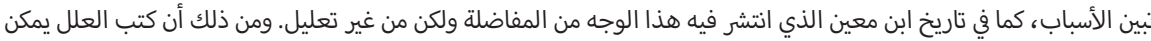

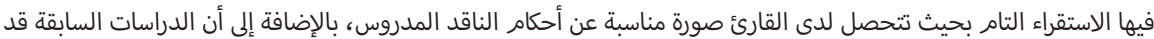

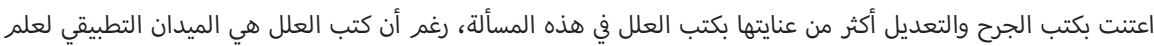
الرجل من جهة، والمؤسس له من جهة أخرى، ففيها الأحكام على الرواة والأحكام على الروايات مع الأسباب والتعليل.

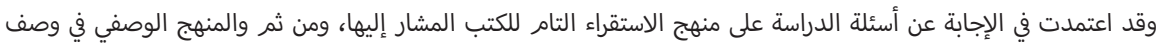

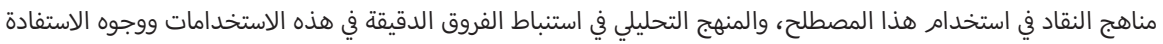

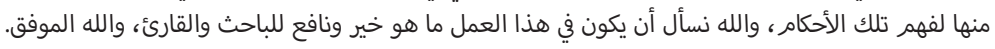

1. القسم النظري: المفاضلة بين الرُّواة عند نقاد الحديث، منهجها وأسبابها

أتوقف في هذا المبحث عند التعريف بأهم مصطلحات البحث، وبمنهج النقاد في إيراد المفاضلات، وأسباب ذكرها، ووجوهها ونماذجها.

1.1. التعريف بمصطلحات البحث

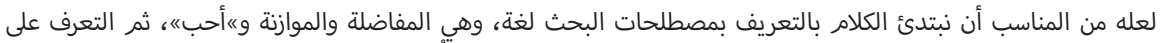

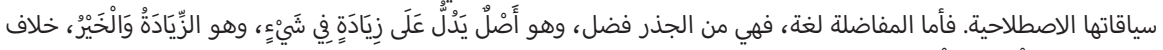

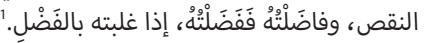

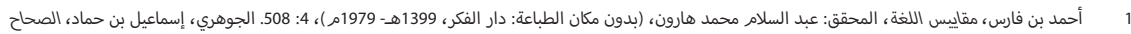

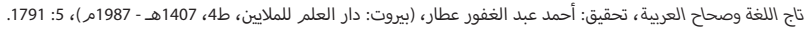




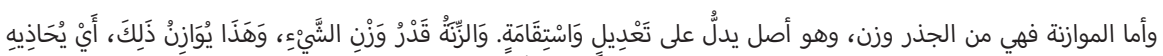

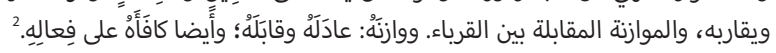

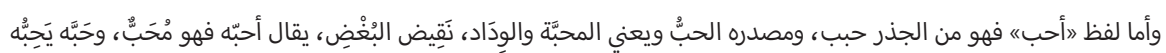
فهو محبوب، والتفضيل منه أحبّ، وهو المقصود فئو هندا.

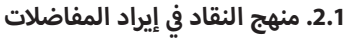

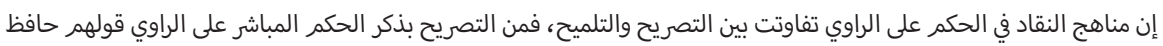

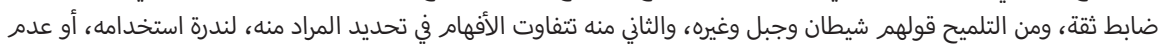
وضوح دلالاته المجازية، أو التعارض بين النقاد في دلالات استخدامه.

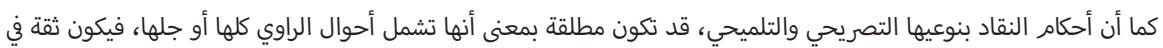

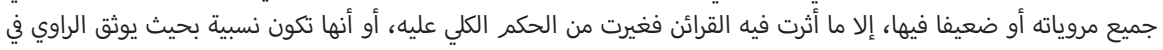

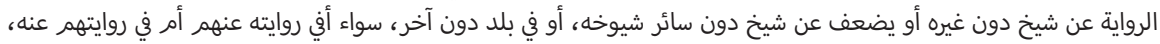
أو في حال معين أو موضوع بذاته دون غيره.

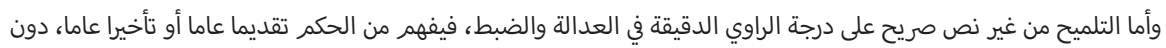

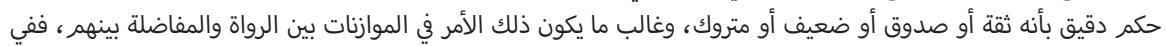

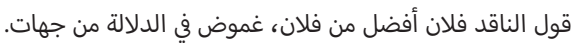

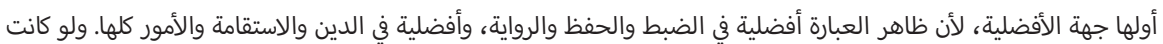

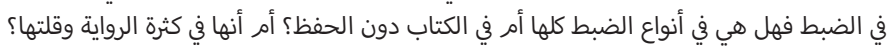
وثانيها مقدار الأفضلية، أهما متقاربان فتكون الأفضلية هي أفضلية التقدم بدرجة واحدة أم متباعدان فتكون أفضلية تقدم بدرجات متعددة؟

وثالثها إطلاق الأفضلية، فهل تعم أفضلية ذلك الراوي على مقابله المواضيع والروايات كلها أمر أنها نسبية تختص بالراله الرواية

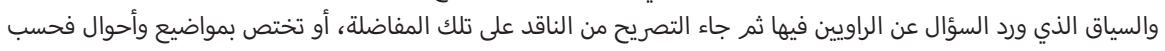
دون غيرهما.

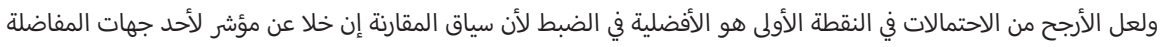

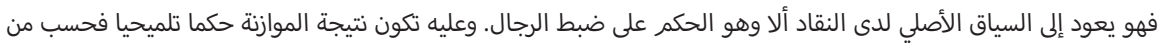

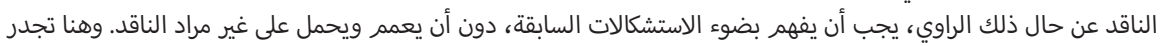

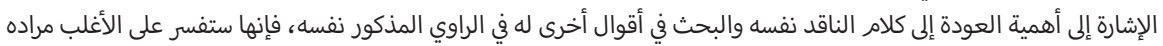
بوجه التفضيل، فكلام النقاد متسق مع نفسه.

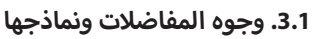

يمكن تقسيم المفاضلات بحسب موضوعها إلى نوعين: الأول: المفاضلات المطلقة: وهي التي لا يتم فيه التصريح بالمقارنة بين راويين بعينهما، بل تكون تفضيلا مطلقا للراوي على الرئل غيره

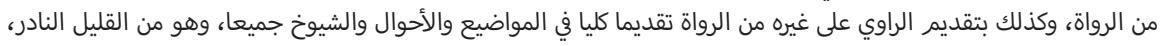

ابن فارس، مقايس اللغة، 6: 107. الذهبي، سير أعلام النبلاء ، تحقيق شعيب الأرناؤوط وحسين الأسد، (بيروت: مؤسسة الرسالة، ط9، 1413هـ الجــ 1993م)، 36: 251-252.

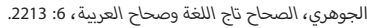

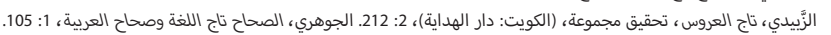

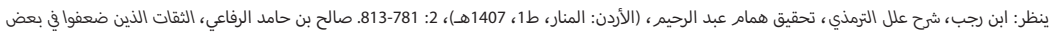

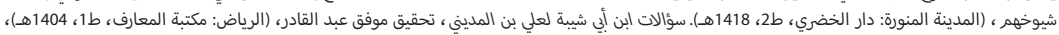

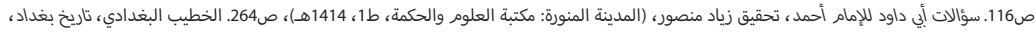
(بيروت: دار الكتاب العربي)، 7: 125. 
ومنه ما قاله يحيى بن معين في سفيان الثوري "ليس أحد يخالف سفيان إلا كان القول قول سفيان«، وأبو حاتم "لا أقدم على ألى

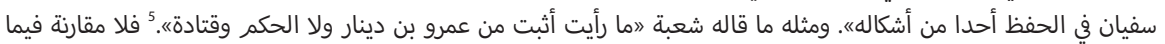
سبق بين سفيان وراوٍ آخر، أو بين عمرو والحكم وقتادة وغيرهم ، وإنما هو مطلق التقديم في الأمور كلها. الثاني: المفاضلات النسبية: وهي التي يتم فيها التصريح بالمقارنة بين راويين أو مجموعة رواة بأعيانهم ، أو التي يتم فيها التصريح

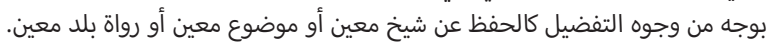

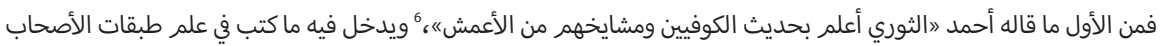

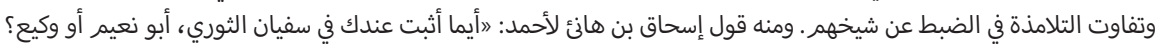

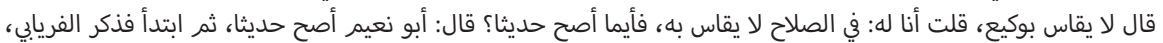

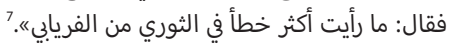

ومن الثاني ما قاله يحيى القطان: 》ما رأيت شاميا أوثق من ثور بن يزيد《، وقاله أبو حاتم أيضا. وموضوع هذه الدراسة هو المفاضلات النسبية إن شاء الله.

\section{1. أهمية المفاضلات وأسباب إيرادها}

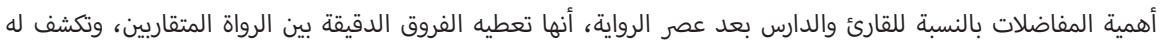

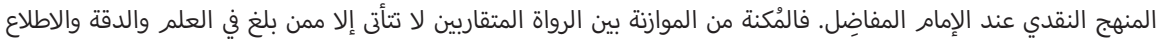
مبلغا واسعا وعميقا.

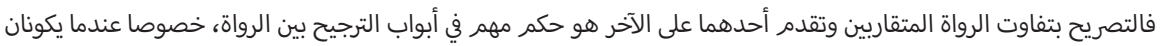

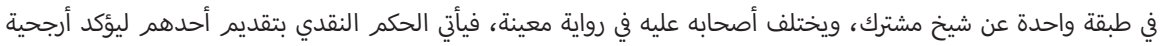

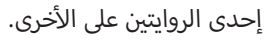

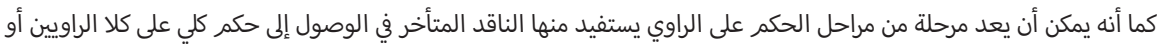
الرواة فيما لو تعددت المفاضلات. وتأتي المفاضلة أحيانا مع بيان أسباب الترجيح فيها وقد تخدل تخلو من ذلك الك كما سلف. وأسباب المفاضلات بين الرواة كثيرة، أذكر منها: -القرابة بين الرواة، كيزيد بن يزيد بن جابر وعبد الرحمن بن يزيد. - اشتراكهم في الاسم والكنية كأشعث بن عبد الملك وأشعث بن سورار. -اشتهارهم بالأخذ عن شيخ معين أو اتحادهم في الطبقة كأبي الزبير بن مسلم وأي سفيان بن نافع عن جابر، وأبان وثابت عن أنس.

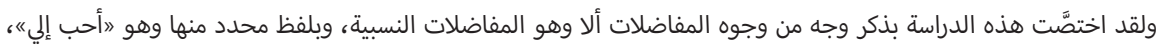

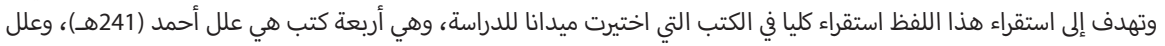

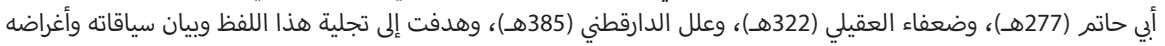

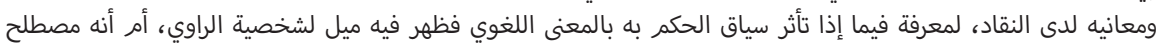

\footnotetext{
ينظر: الخطيب، تاريخ بغداد، 9: 168. ابن أبي حاتم ، علل ابن أبي حاتم ، تحقيق: فريق من الباحثين، (بدون مكان الطباعة: مطابع الحميضي، ط1، 1427هـ - 2006 2006م)، 2:

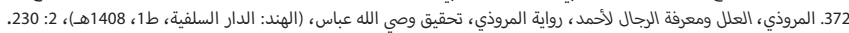

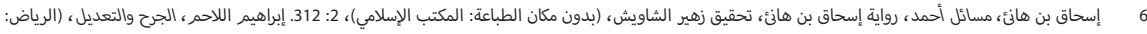

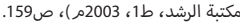
7 7

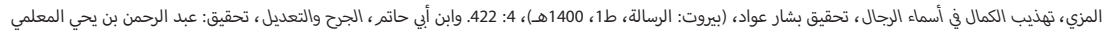

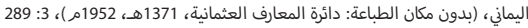

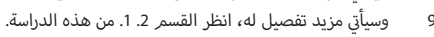
10
} 


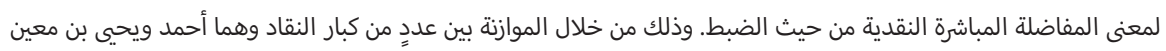

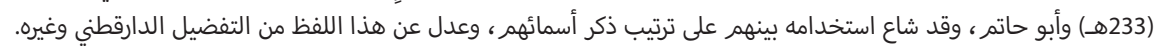

\section{2. القسم التطبيقي: المفاضلة بلفظ ״أحب إليَّه عند نقاد الحديث}

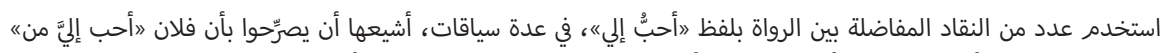

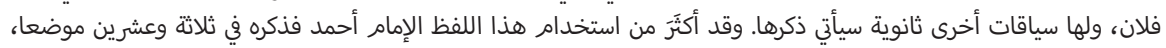

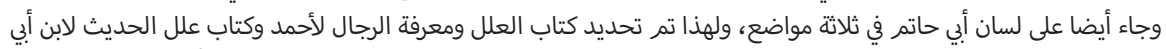

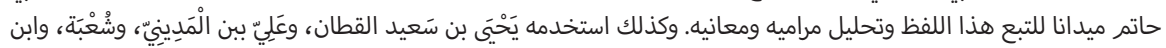

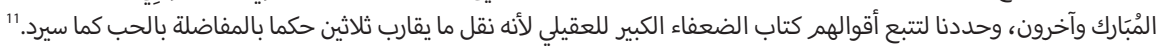
وقسمت سياقات استخدام لفظ المفاضلة بالمحبة وكما وجدته لدى النقاد إلى نوعين، سياقات أصلية وسياقات ثانوية، فالأصلية

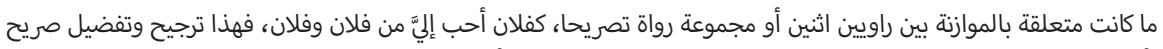

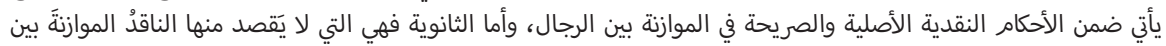

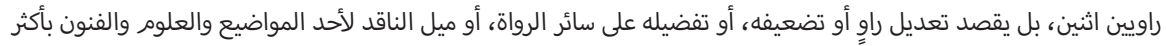

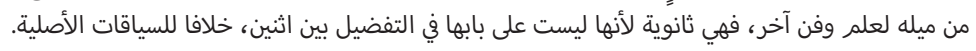

1.2. السياقات الأصلية في المفاضلة بين الرواة بالمحبة

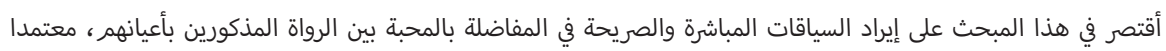

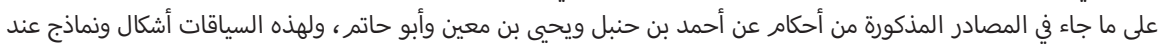

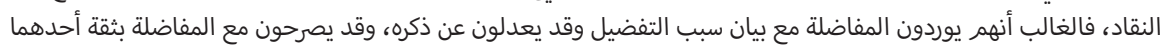

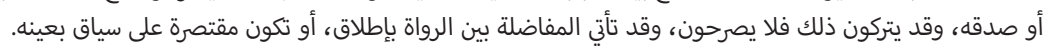

والغاية من ذلك تحرير معنى المفاضلة بالحب عند النقاد موضوع الدراسة، وإلحاقها بالمصطلح النقدي الأشهر أو الأوضح.

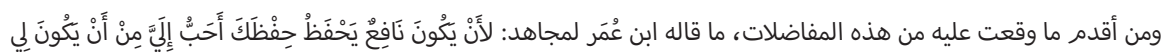

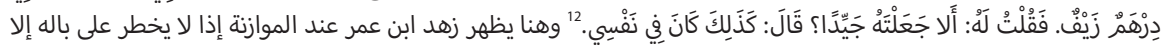

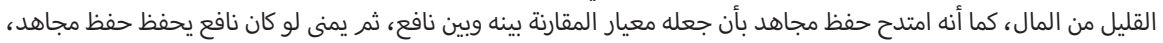

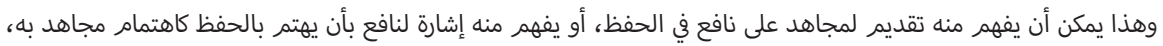
فالمخاطب هو مجاهد والرسالة هي لنافع، والله أعلم.

\subsection{2. المفاضلة بلفظ »أحب إليَّ) مع التصريح بالحكم النقدي دون أسبابه}

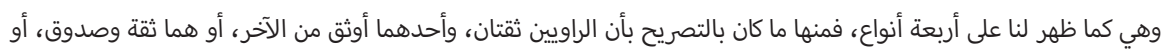

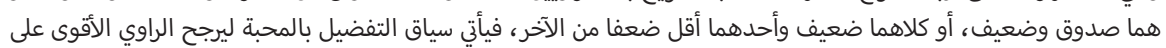
الأضعف، وذلك على حسب اجتهاد الناقد، وقد يتفق النقاد على ذلك وقد أنتا تتباين آراؤهم كما في الأمثلة الآتية.

\subsubsection{2 التصريح بالتفضيل لأن أحد الراويين أوثق من الآخر}

بأن يصرح الناقد أن الراوي أعلى لديه من فلان، وكلاهما ثقتان:

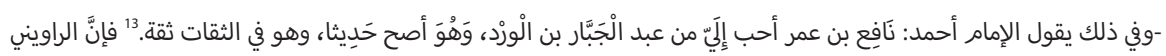

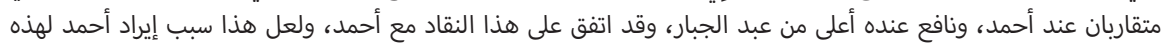
المفاضلة.

\footnotetext{
11 الأرقام المذكورة هي حصيلة الاستقراء الذي قام به الباحث في الكتب المذكورة، وهي ميدان الدراسة التطبيقية في واقع الأمر بحيث لم يستغن الباحث مما سبق سوى ما حصل فيه التكرار.

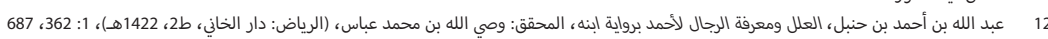
13
} 


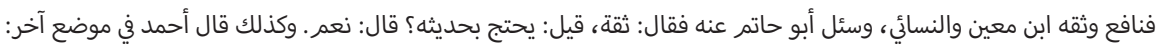

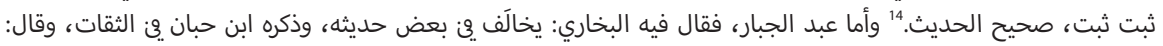

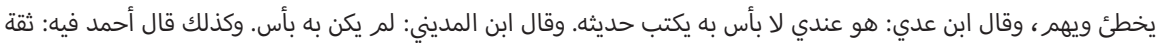

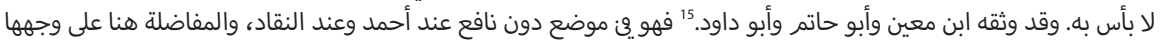

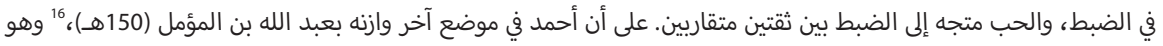

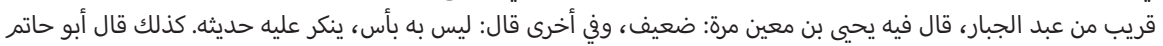

$$
\text { وأبو زرعة: ليس بقوي. }
$$

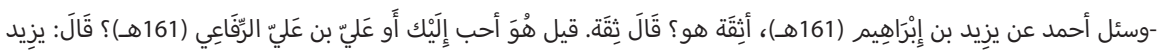

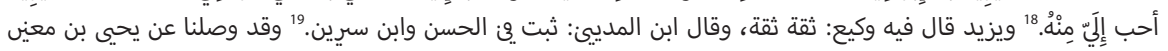

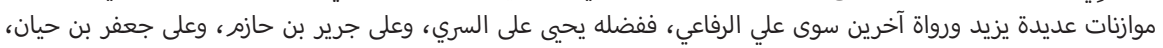

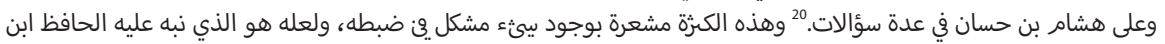
حجر بقوله ثقة ثبت إلا في روايته عن قتادة فئاد ففيها لين.

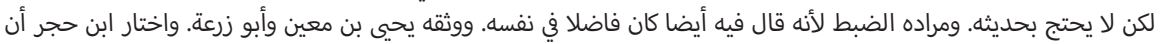

يقوله فيه: لا بأس به، وكان عابدا.

وعليه فإن لفظ المحبة هنا جاء على المعنى الاصطلاحي بالتفضيل بين الرواة المتجه إلى الضبط.

2.1.1.2 التصريح بتفضيل الثقة على الصدوق

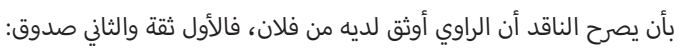

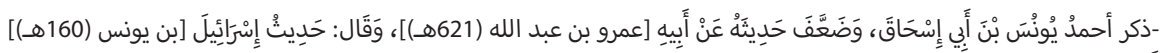

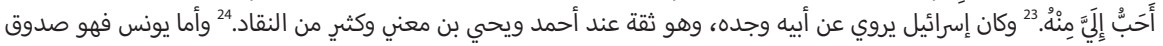

يهم قليلا.

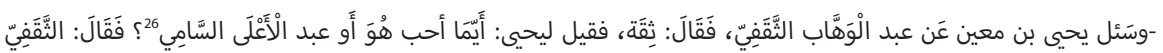

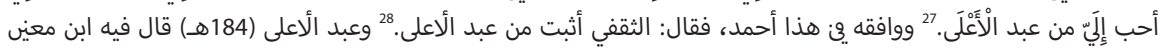

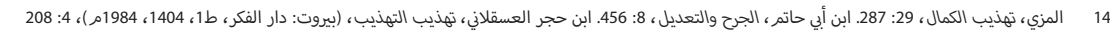

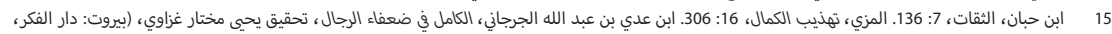

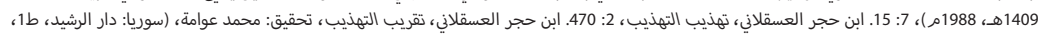
$563:$ 1406هـ 1406، 1986مـ، 1980. 16 16 17 18 18 . 17

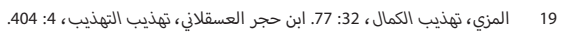

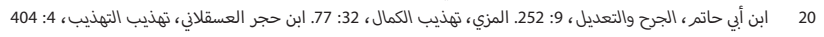
21 22 23 23

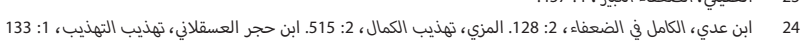
25

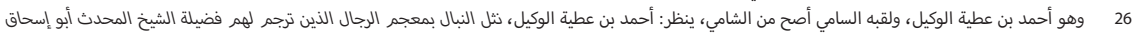

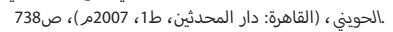
27

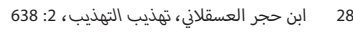


في موضع آخر، وأبو زرعة: ثقة، وقال أبو حاتم : صالح الحديث. ${ }^{29}$ وعبد الوهاب (194هـ) وثقه ابن معني ين مواضع آخر. وقال:

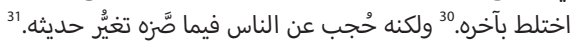

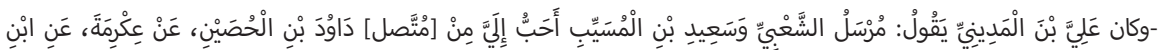

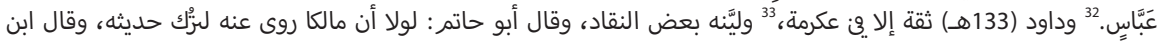

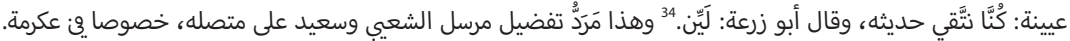

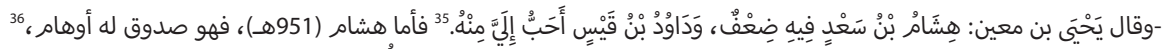

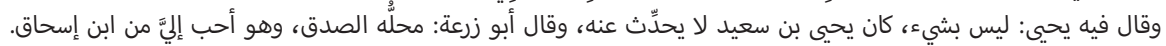
وقال النسائي: ضعيف. وقال مرة: ليس بالقوي.

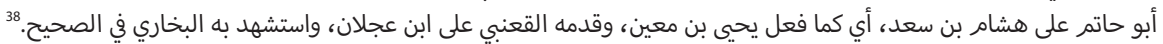

وكذلك الأمر هنا، فإن لفظ المحبة جاء على المعنى الاصطلاحي بترجيح الراوي الأضبط على مقابله.

3.3.1.2 التصريح بتفضيل الصدوق على الضعيف

بأن يصرح الناقد أن الراوي أعلى لديه من فلان، والأول صدوق والثاني ضعيف:

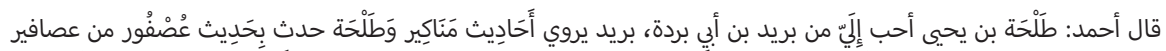

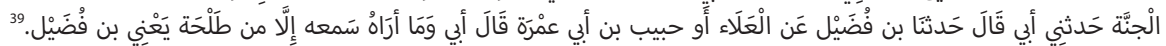

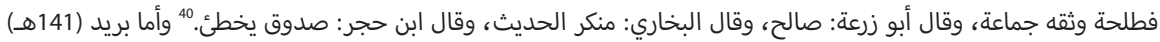

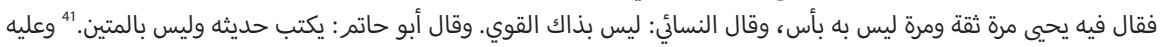

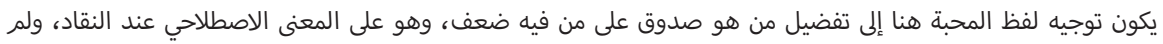

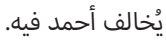

\section{(4.1.1.2 التصريح بتفضيل الراوي الأقل جرحا من مقابله}

بأن يصرح الناقد أن الراوي أقل ضعفا لديه من فلان، وكلاهما ضعيف:

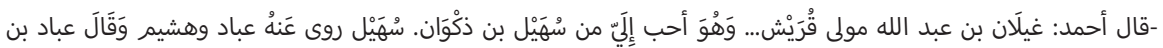

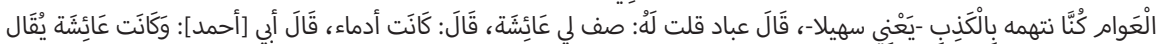

شقراء بَيْضَاء.

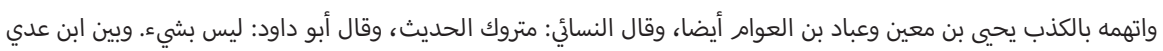
ضعفه وأكد سبب تكذيبه بقوله: وسهيل بن ذكوان هذا مع ما ينسب إلى الكذب، ليس له كثير حديث، وإنما لم إند يعتبر الناس

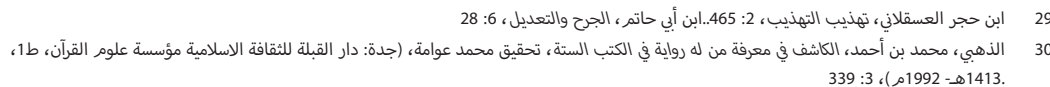
31 ابن الكيال، أبو البركات محمد بن أحمد، الكواكب النيرات في معرفة من الرواة الثقات، تحقيق: عبد القيوم عبد رب النبي، (بيروت: دار المأمون، ط1، 1981مر)، 1: 314 32

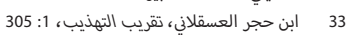

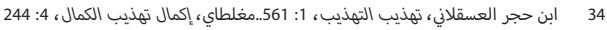

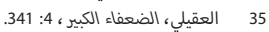
36 ابن حجر العسقلاني، تقريب التهذيب، 35 37 36

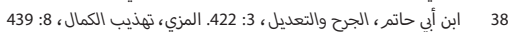
39 40 40

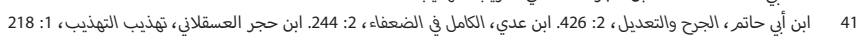
42 
بكذبه في كثرة رواياته؛ لأنه قليل الرواية، وإنما تبينوا كذبه بمثل ما بينا، أن عائشة كانت سوداء، وإن إبراهيم النخعي كان كبير

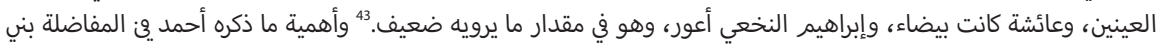

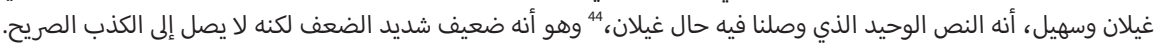

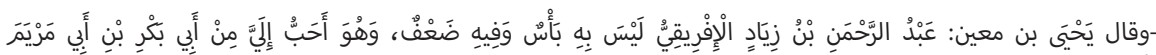

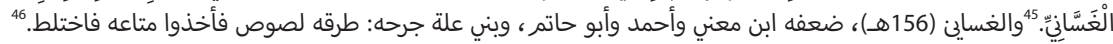
وعليه فإن لفظ »أحب" هنا أعطنا معنى كونه أقل ضعفًا من حال الراوي المعروف جرحه.

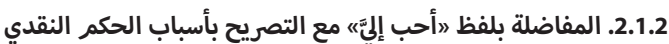

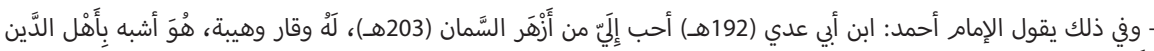

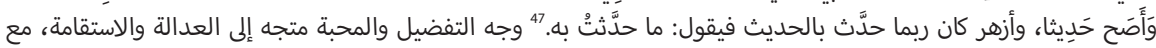

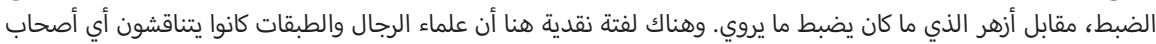

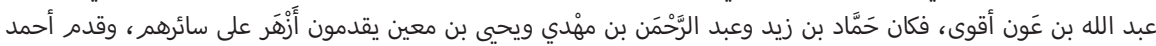

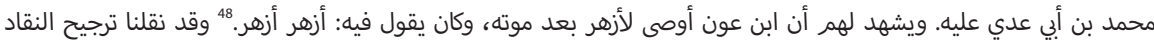

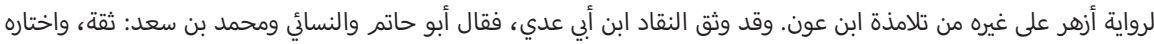

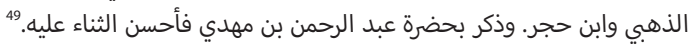

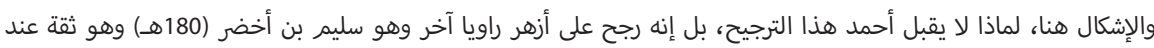
جمهور النقاد، ؤ وكأنه يفرُ من الإقرار بتقدمه فحسب، أحما، أو أن هناك ما حمل أحمد على ذلك.

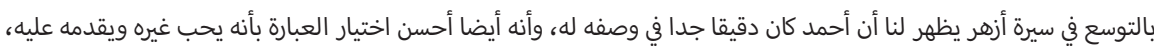

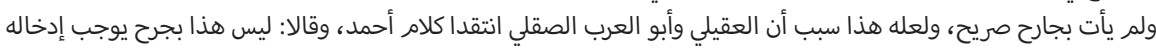

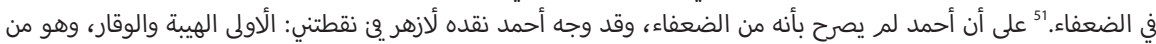

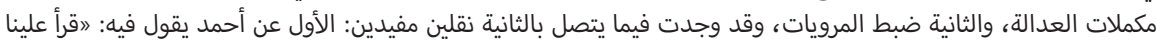

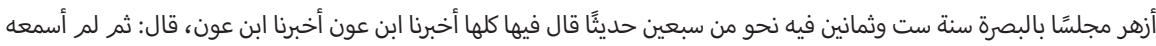

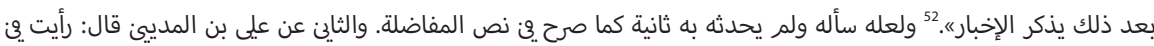

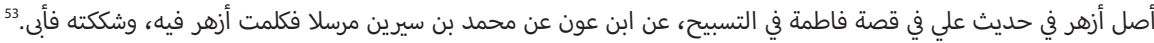

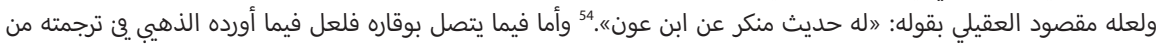

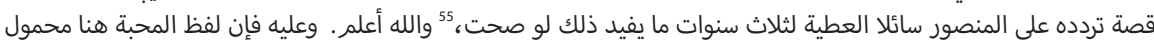
على تقديم اصطلاحي مشفوع بنقد وجرح لأحد الرواة عن منزلته كثقة.

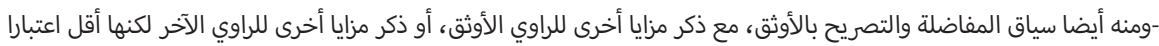

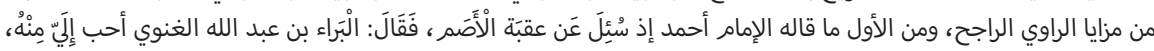

4334 ابن عدي، الكامل في الضعفاء، 4: 521. ابن حجر العسقلاني، لسان الميزان، تحقيق: عبد الفتاح أبو غدة، (بيروت: دار البشائر الإسلامية، ط1، 2002م)، 4: 210

44

4 45

46

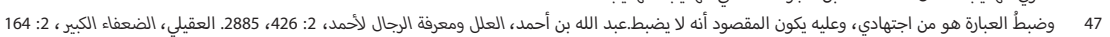

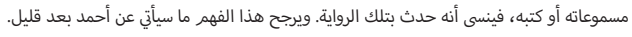
48

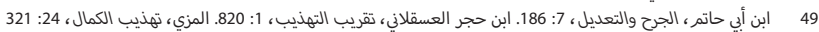

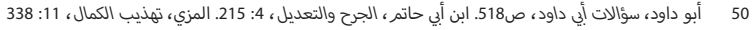
51 52 5 53 53 ابن حجر العسقلاني، تهذيب التهذيب، 54 54 55 


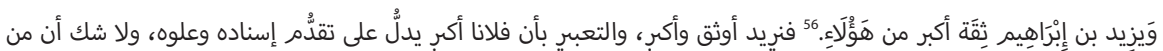

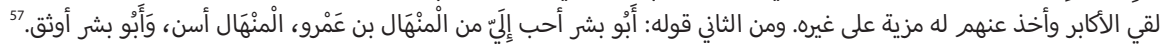
وعليه فإن لفظ المحبة فيما سبق، ينصرف إلى المعنى الاصطلاحي بتقديم أحد الرواة في الحفظ والضبط على أقرانه في الطبقة والعلم هنا.

\subsection{2. المفاضلة بلفظ »أحب إليَّه في سياق إسناد أو أسانيد بعينها}

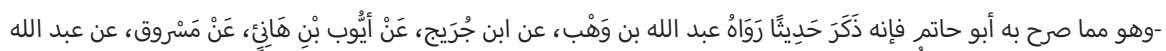

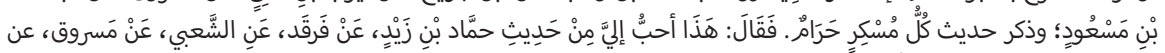

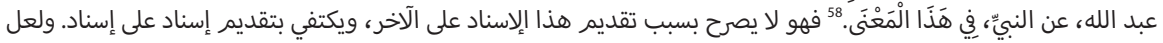

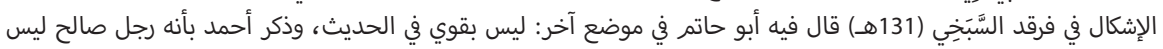

بقوي في الحديث لم يكن صاحب حديث، وقدَ فال بأنه ضعيف مرة.

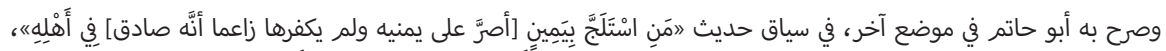

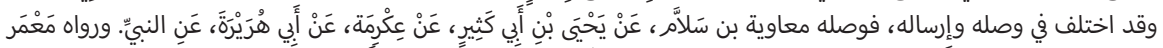

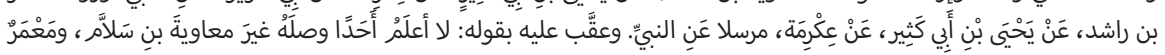

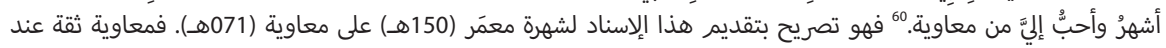

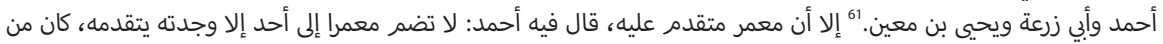

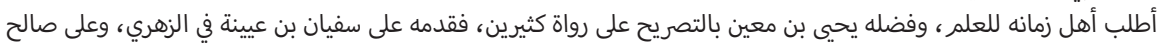

بن كيسان ويونس مطلقا. وعدَّه علي بن المديني وأبو حاتم فيمن انتهى إليهم الإسناد ودار عليهم .

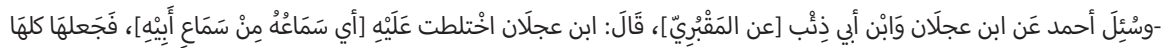

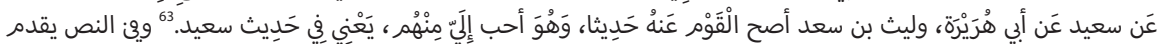

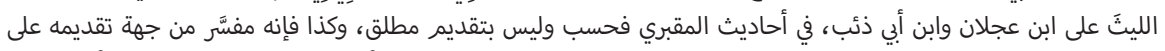

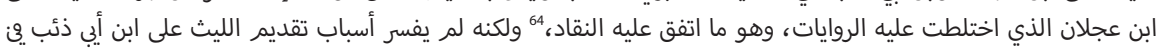

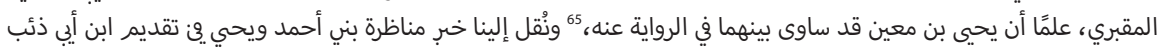

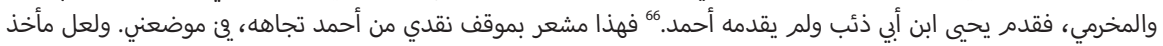

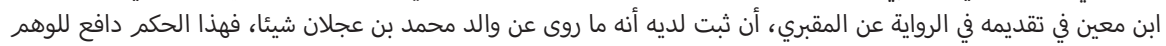

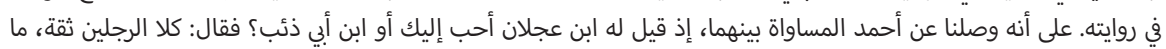

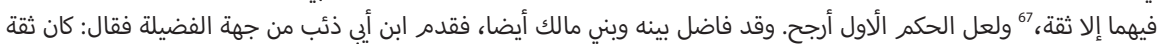

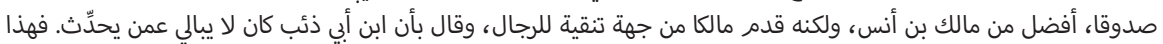

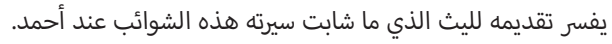
فالمحبة هنا اصطلاحية على معنى الترجيح والتفضيل.

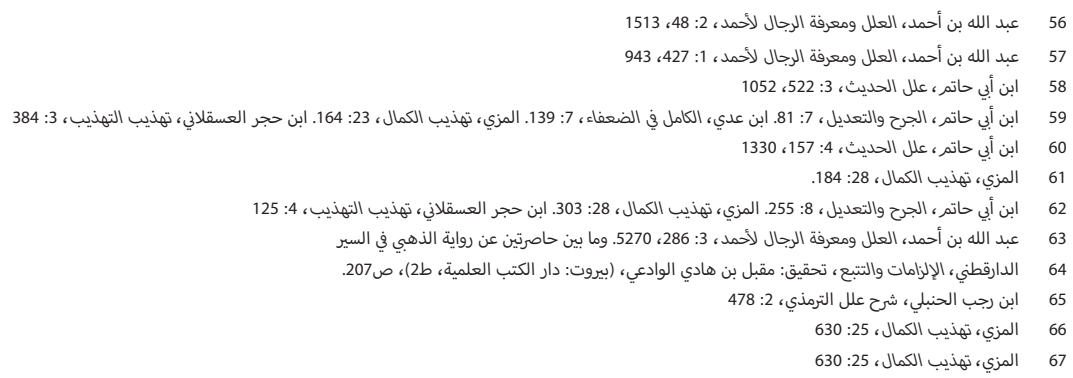




\subsection{2. المفاضلة بلفظ »أحب إليَّه من غير تصريح بوجه التقديم أو أسبابه}

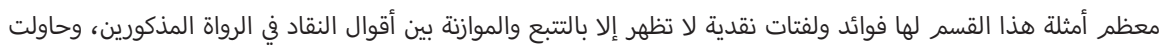

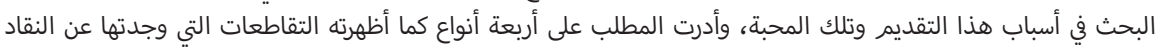

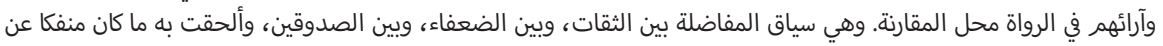
أي سياق مما سبق.

\subsubsection{2 ما جاء في سياق المفاضلة بين الثقات}

بأن يصرح الناقد بالتفضيل، وكلا الراويين ثقتان:

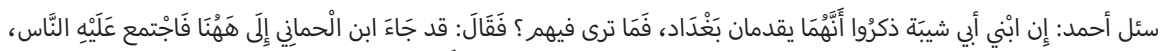

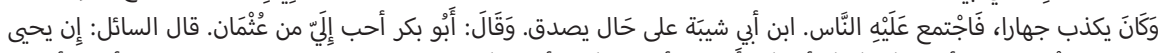

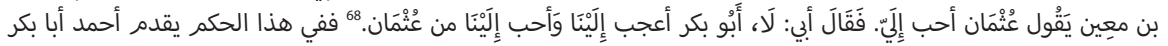

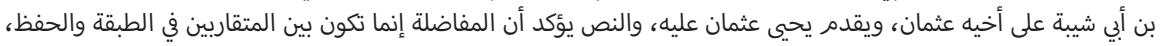
وابني أبي شيبة هكذا.

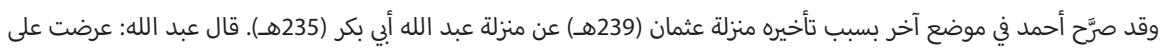

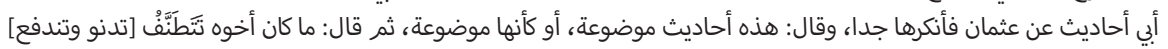

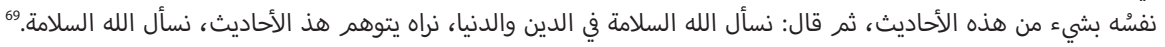

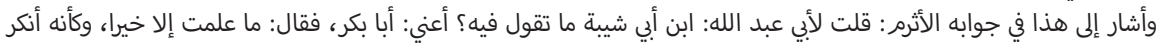

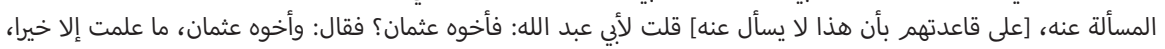
وأثنى عليه، وقال: عثمان رجل سليم.

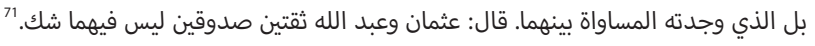
وعليه فإن المفاضلة بالمحبة هنا على سياقها الاصطلاحي بالتقديم والترجيح.

2.4.1.2 ماء جاء في سياق المفاضلة بين الضعفاء

بأن يصرح الناقد بالتفضيل، وكلا الراويين ضعيفان:

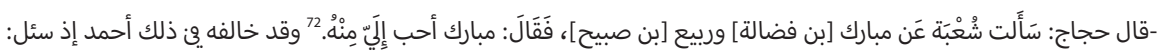

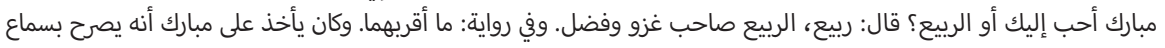

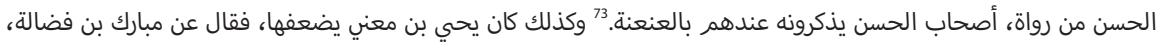

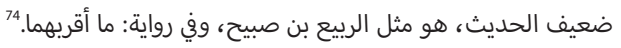

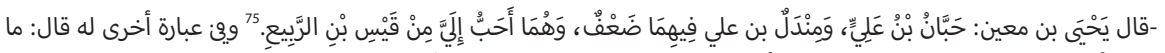

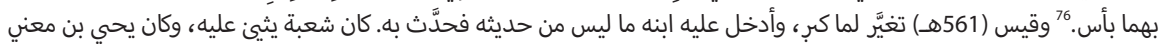

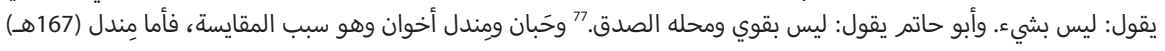

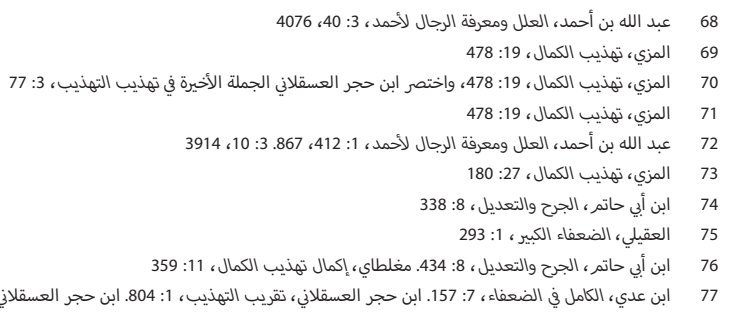




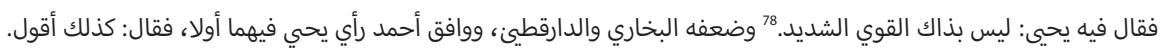

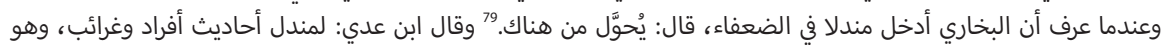
ممن يكتب حديثه.

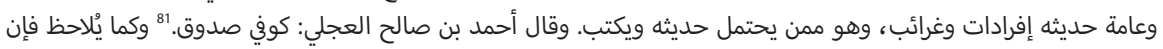

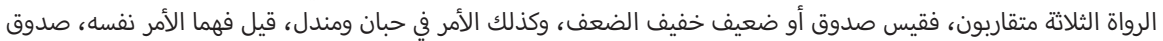

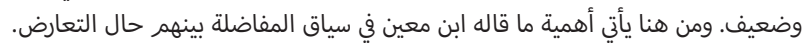
وعليه فإن المفاضلة بالمحبة هنا على سياقها الاصطلاحي بالتقديم والترجيح. 3.4.1.2 ما جاء في سياق المفاضلة بين الصدوقين بأن يصرح الناقد بالتفضيل، وكلا الراويين صدوقان:

وقد عرفنا أنهم صدوقين وليسوا من الضعفاء، لأن الناقد يعقب مفاضلة بالتصريح بعدم ضعف المقابل

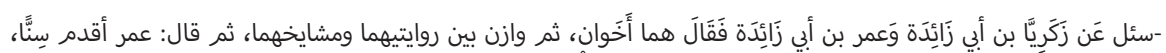

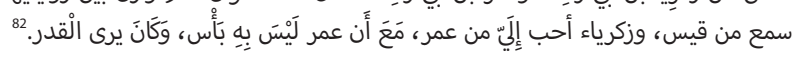

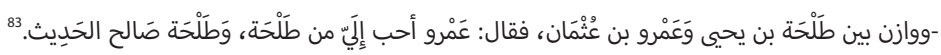

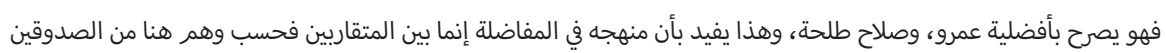
ممن لم يخف ضبطه ولم يكن من الضعفاء.

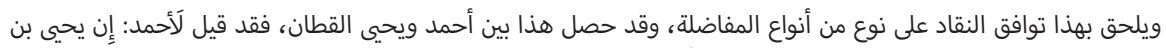

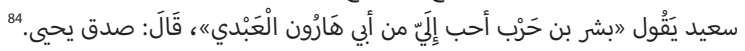
وعليه فإن المفاضلة بالمحبة هنا على سياقها الاصطلاحي بالتقديم والترجيح.

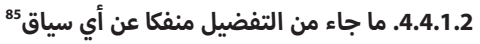

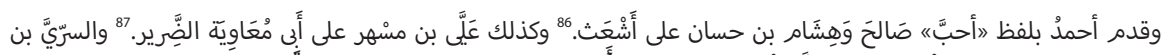

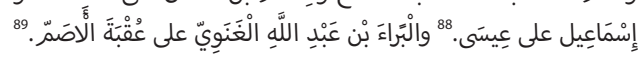

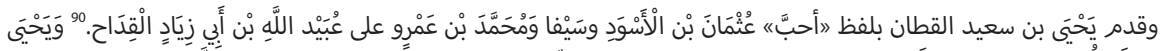

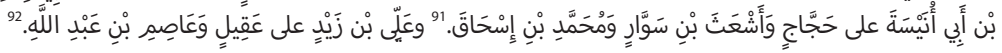

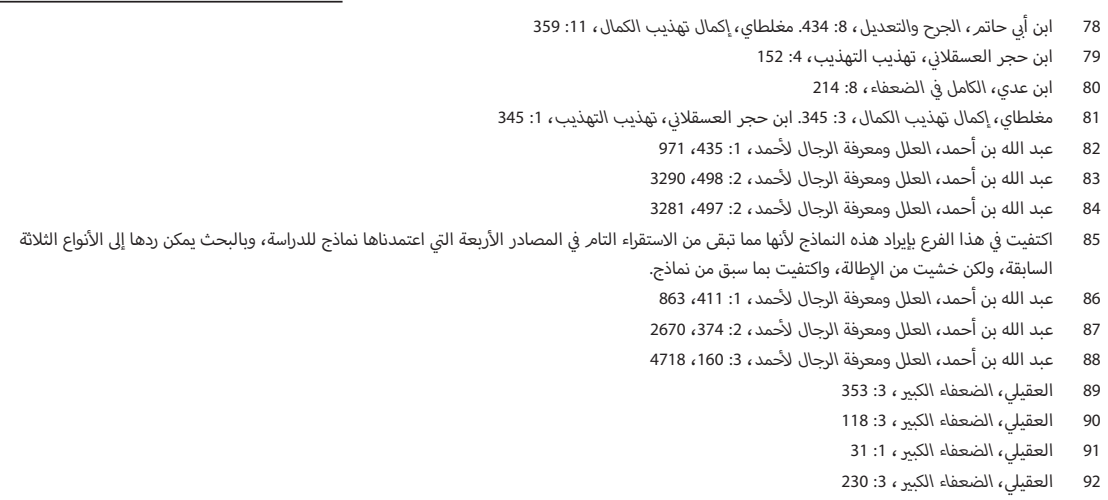




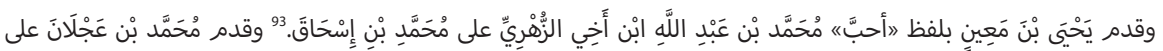

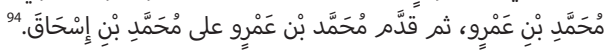

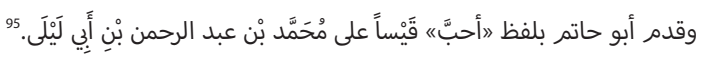
وهذا السياق أيضا على السياق الاصطلاحي للفظ المحبة.

2.2. - السياقات الثانوية للمفاضلة بالحب عند النقاد

أنتقل هنا إلى ذكر السياقات الثانوية، وهي الواردة لا في سياق الموازنة بين راويين وإنما في سياق تعديل راوٍٍ بعينه أو تضعيفه، وفي سياق المفاضلة بين دقيق علوم الحديث وجليله.

1.2.2 في سياق تعديل راو وبيان فضله

بأن يصرح الناقد بلفظ التفضيل ولكن بغرض توثيق الراوي أو أحوال روايته:

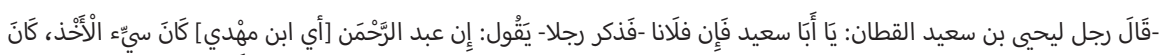

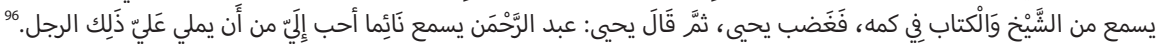
فالغرض هنا مطلق تعديل ابن مهدي.

-وكذلك كان يقول: عرض عبد الرَّْمَن بن مهْدي أحبِ إلِِّّ من سَماع غَهره.

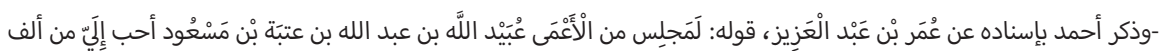

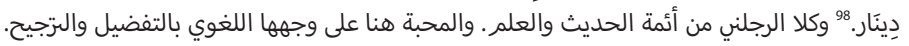

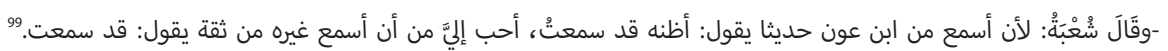

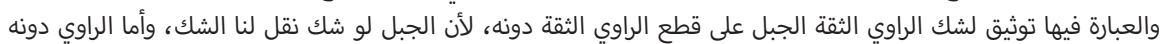

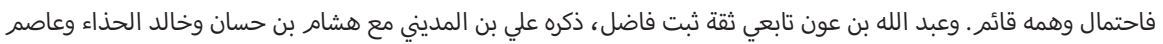

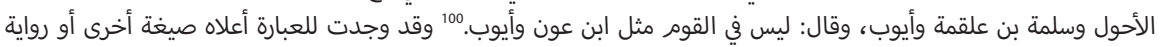

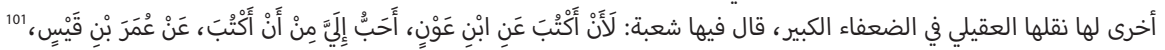

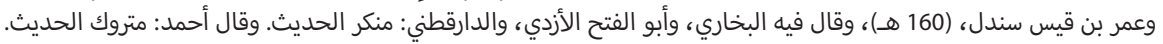

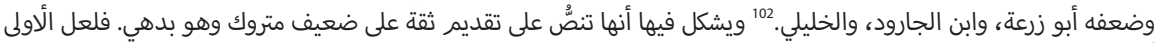

وسياق المحبة هنا سياق نقدي بامتياز يعني ترجيح الراوي وتفضيله، ولكن الطرف المقابل من المقارنة وفيه السماع من النائم أو السماع حالة الظن، فاللفظ فيها ليس على ظاهره. 


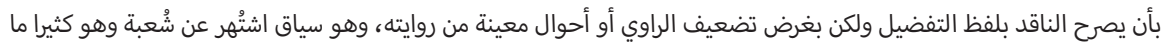

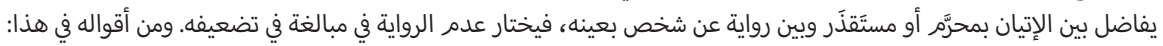

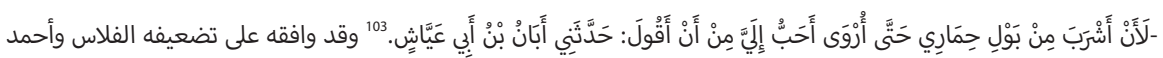

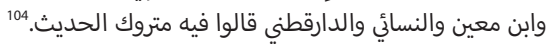

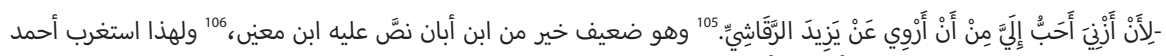

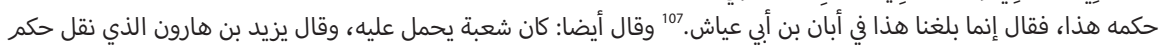

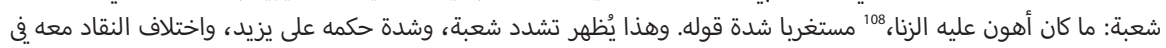

الحكم.

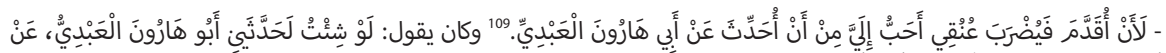

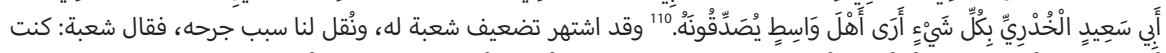

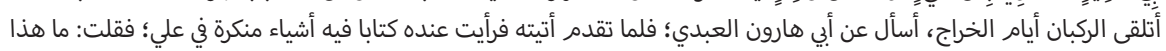

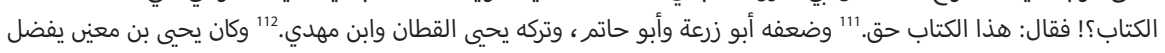

عليه بشر بن حرب كما سلف.

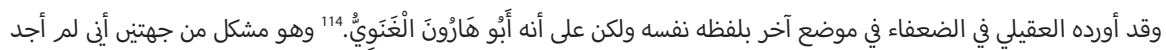

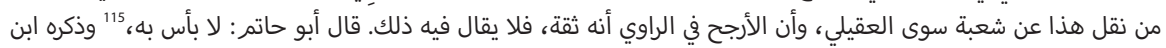

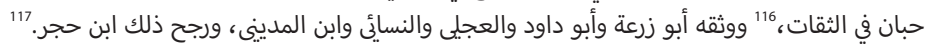

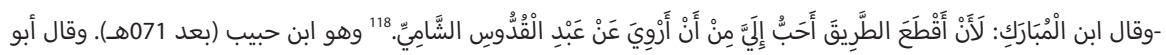

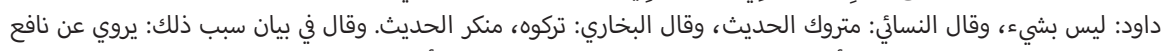
ومجاهد والشعبي ومكحول وعطاء أحاديث مقلوبة. اللغوي بالتفضيل والترجيح.

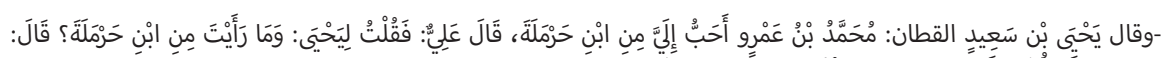

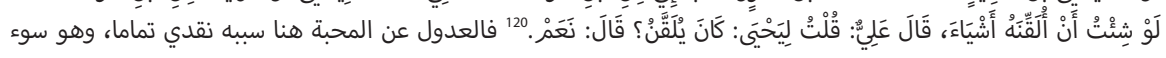
ضبطه وقبوله التلقين.

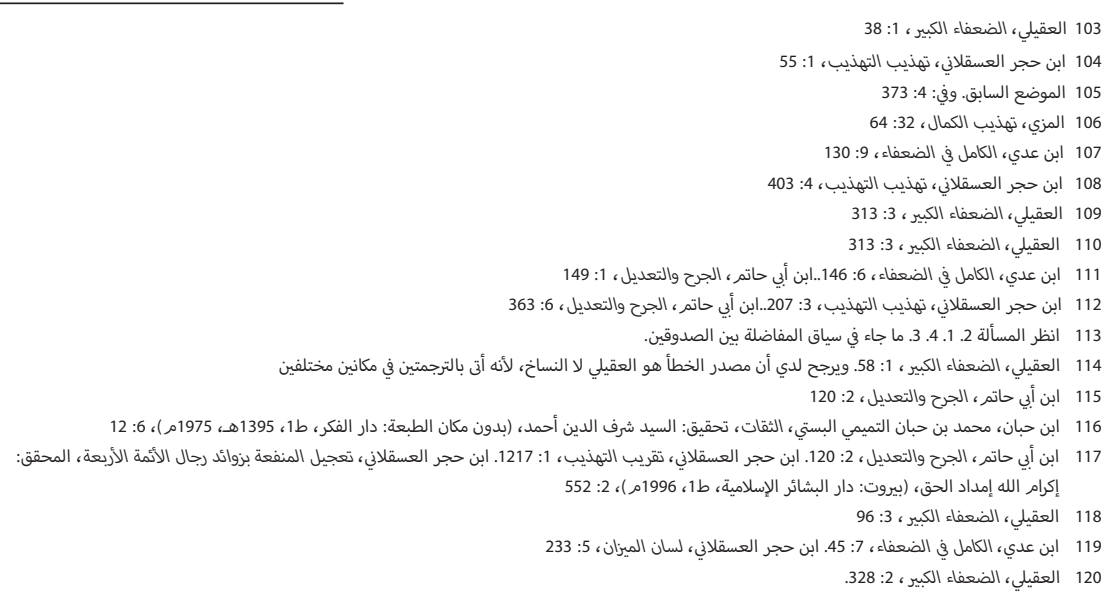


ولكن يظهر في هذا السياق الأثر الذاتي للراوي في اختيار اللفظ ووجه المقارنة، فمن النقاد من كان شديدا قاسيا في عبارته، ومنهم

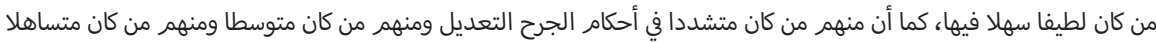

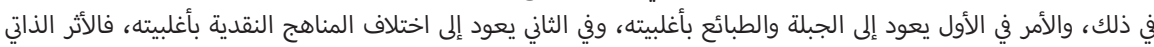

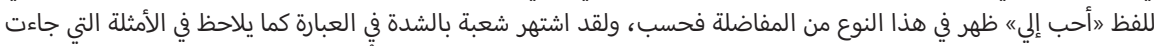

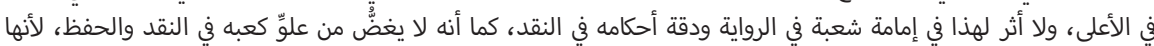

فطرته وجبلته التي خُلق عليها.

\subsection{2 وفي سياق المفاضلة بين أنواع الحديث}

بأن يصرح الناقد بلفظ التفضيل ولكن بغرض إبراز قيمة علوم معينة من علوم الحديث:

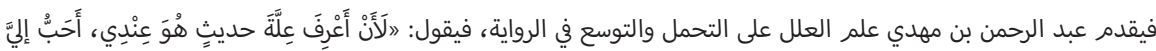

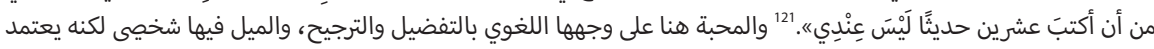

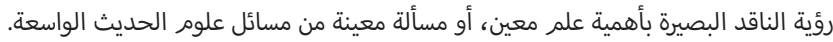

النتائج

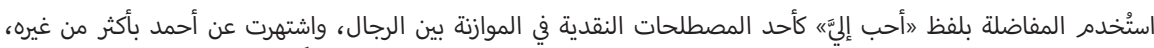

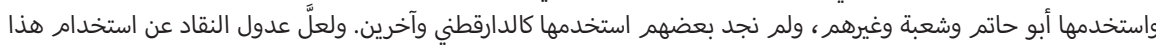

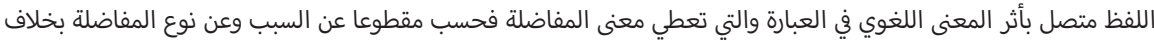

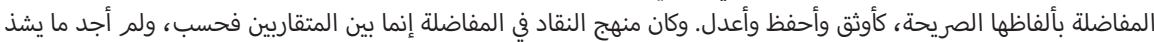

عن هذه القاعدة إلا نصا واحدا وهو أيضا غير صرأحفي وأعدل وكان في ذلك.

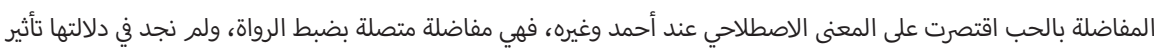

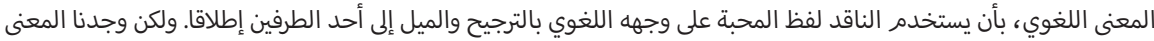

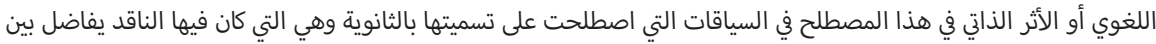

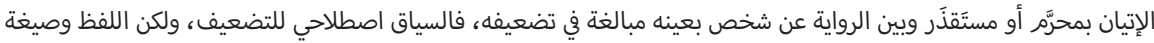

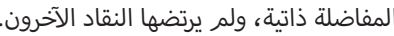

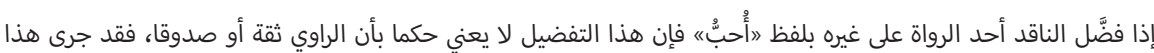

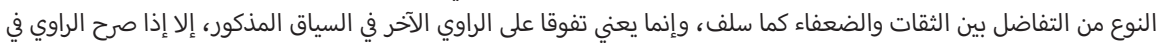

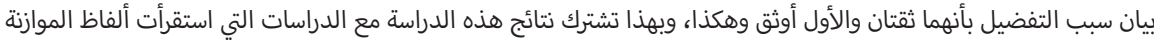
الأخرى عند النقاد.

ويلاحظ لطف عبارة المحدثين باختيارهم هذه المصطلحات العذبة في التعبير عن آرائهم النقدية، وهذا من محسنات العلوم ومكملاتها.

المصادر

ابن أبي حاتم، الجرح والتعديل، تحقيق: عبد الرحمن بن يحي المعلمي اليماني، حيدر آباد: دائرة المعارف العثمانية، 1952/01371 مر.

، علل ابن أبي حاتم ، تحقيق: فريق من الباحثين، ط1، الرياض: مطابع الحميضي، 1427هـ - 2006م.

ابن أيي شيبة، سؤالات ابن أيي شيبة لعلي بن المديني، تحقيق موفق عبد القادر، ط1، الرياض: مكتبة المعارف،

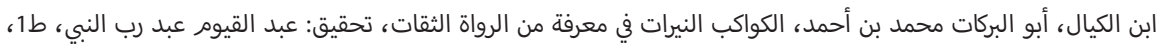
بيروت: دار المأمون، 1981 مر المرات 
ابن حبان، محمد بن حبان التميمي البستي، الثقات، تحقيق: السيد شرف الدين أحمد، ط1، بيروت: دار الفكر، 1395، 1975م. ابن حجر العسقلاني، تعجيل المنفعة بزوائد رجال الأئمة الأربعة، تحقيق: د. إكرام الله إمداد الحق، ط1، بيروت: دار البشائر،

$$
\begin{aligned}
& \text { ، تقريب التهذيب، تحقيق: محمد عوامة، ط1، سوريا: دار الرشيد، 1986/01406مر. }
\end{aligned}
$$

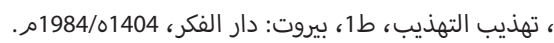

$$
\begin{aligned}
& \text { ، لسان الميزان، تحقيق: عبد الفتاح أبو غدة، ط1، بيرون، دارلكر، بيروت: دار البشائر الإسلامية، 2002م. }
\end{aligned}
$$

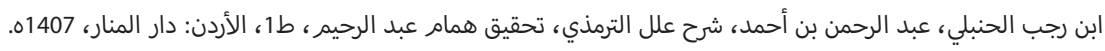

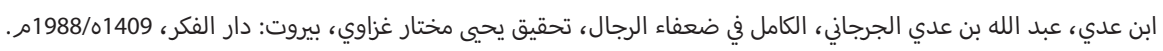

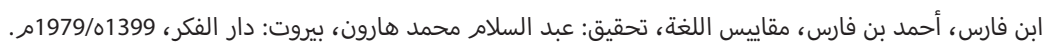
أبو داود، سليمان بن الأشعث، سؤالات أبي داود للإمام أحمد، تحقيق زياد منصور، ط1، المدينة المنورة: مكتبة العلوم والحكمة، الحما،

إسحاق بن هانئ، مسائل أحمد، رواية إسحاق بن هانئ، تحقيق زهير الشاويش، بيروت: المكتب الإسلامي، ب.ت.

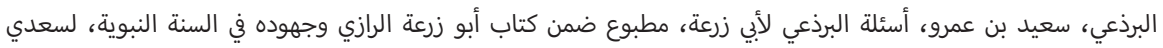

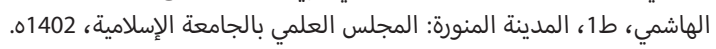

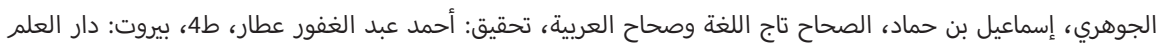

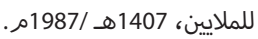
الخطيب البغدادي، أحمد بن علي، تاريخ بغداد، بيروت: دار الكتاب العربي.

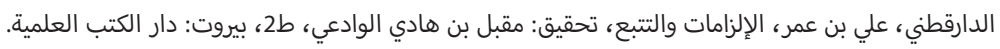

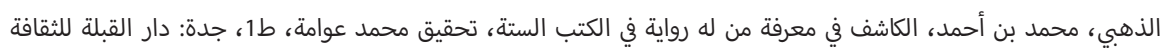
الاسلامية مؤسسة علوم القرآن، 1992/01413م.

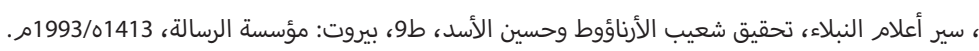

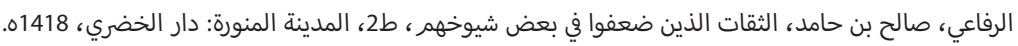

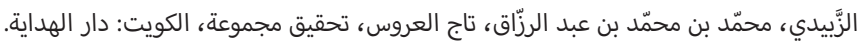

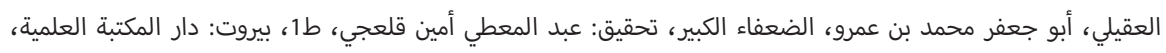
1984/01404 اللاحم ، إبراهيم ، الجرح والتعديل، ط1، الرياض: مكتبة الرشد، 2003م.

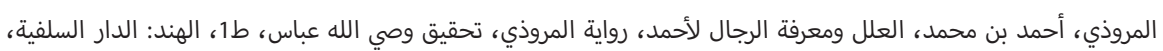
.01408

المزي، يوسف بن عبد الرحمن، تهذيب الكمال في أسماء الرجال، تحقيق بشار عواد، ط140، بيروت: مؤسسة الرسالة،

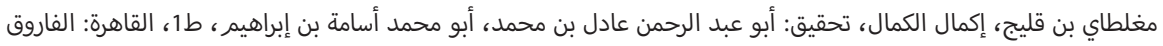

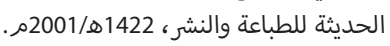
الوكيل، أحمد بن عطية، نثل النبال بمعجم الرجال الذين ترجم لهم فضيلة الشيخ المحدث أبو إسحاق الحويني، ط1، القاهرة:

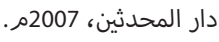




\section{KAYNAKÇA}

Cevherî, İsmâîl b. Hammâd. es-Sihah tâcü'l-lüga ve sahîhu'l-Arabiyye. Thk. Ahmed Abdulgafûr Attâr. 4. Baskı. Beyrut: Dâru'I-İlm li-I'melâyîn, 1987/1407.

Dârekutnî, Alî b. Ömer. el-ilzâmât ve't-tetebbu'. Thk. Mukbil b. Hâdî el-Vâdiî. 2. Baskı. Beyrut: Dâru'l-Kütübi'l-IImiyye, ts.

Ebû Dâvud, Süleymân b. el-Eş'as. Suâlât Ebî Dâvud li'l-Imâm Ahmed. Thk. Ziyâd Mansûr. 1. Baskı. el-Medînetü'l-Münevvere: Mektebetü'l-Ulûm ve'l-Hikme, 1414.

Hatîb el-Bagdâdî, Ahmed b. Alî. Târîhu Bagdâd. Beyrut: Dâru'l-Kitâbi'l-'Arabî, ts.

İbn 'Adî, Abdullāh b. Adî el-Cürcânî. el-Kâmil fî duafâi'r-ricâl. Thk. Yahyâ Muhtâr Gazâvî. Beyrut: Dâru'l-Fikr, 1988/1409.

İbn Ebî Hâtim. 'ilel İbn Ebî Hâtim. Thk. Ferîk mine'l-bâhisîn. 1. Baskı. Riyad: Matâbi' elHumeydî, 1427/2006.

İbn Ebî Hâtim. el-Cerh ve't-ta'dîl. Thk. Abdurrahmân b. Yahyâ el-Mü'allimî el-Yemânî. Haydarabad: Dâru'l-Ma'rif el-Usmânîyye, 1371/1952.

İbn Ebî Şeybe. Suêlât İbn Ebî Şeybe li-'Ali b. el-Medînî. Thk. Muvaffak Abdulkâdir. 1. Baskı. Riyad: Mektebetü'l-Meârif, 1404.

İbn Fâris, Ahmed b. Fâris. Mekâyîsü'l-Lüga. Thk. Abdusselam Muhammed Harun. Beyrut: Dâru'l-Fikr, 1399/1979.

İbn Hacer el-Askalânî. Lisânü'I-Mîzân. Thk. Abdülfettah Ebû Gudde. 1. Baskı. Beyrut: Dâru'lBeşâiri'l-İslâmiyye, 2002.

İbn Hacer el-Askalânî. Ta'cîlü'l-menfa'a bi zevâidi ricâli'l-eimme'l-erbea. Thk. İkrâmu'l-Allah İmdâdü'l-Hak. 1. Baskı. Beyrut: Dâru'l-Beşâir, 1996.

İbn Hacer el-Askalânî. Takrîbü't-Tehzîb. Thk. Muhammed Avvâme. 1. Baskı. Suriye: Dâru'rReşîd, 1406/1986.

İbn Hacer el-Askalânî. Tehzîbü't-Tehzîb. 1. Baskı. Beyrut: Dâru'l-Fikr, 1406/1984.

İbn Hibbân, Muhammed b. Hibbân et-Temîmî el-Bustî. es-Sikât. Thk. Es-Seyyid Şerfü'd-dîn Ahmed. 1. Baskı. Beyrut: Dâru'l-Fikr, 1395/1975.

İbn Receb El-Hanbeli, Abdurrahmân b. Ahmed. Şerh 'ilel et-Tirmizî. Thk. Hemmâm Abdurrahim. 1. Baskı. Ürdün: Dâru'l-Menâr, 2002.

İbnü'l-Keyâl, Ebu'l-berekât, Muhammed b. Ahmed. el-Kevâkibü'n-nîrât fî m’arifeti mine'lrüvâti's-sikât. Thk. Abdülkayyûm Abd Rabbin'-nebî. 1. Baskı. Beyrut: Dâru'l-Me'mûn, 1971.

İshâk b. Hâni'. Mesâil Ahmed rivâyet İshâkb. Hâni'. Thk. Züheyr eş-Şâvîş. Beyrut: El-Mektebü'lİslâmî, ts.

Lâhhâm, İbrâhim. el-Cerh ve't-ta'dîl. Riyad: Dâru'r-Rüşd, 2003.

Mervezî, Ahmed b. Muhammed. el-'llel ve ma'rifetü'ricâl li-Ahmed. Rivâyetü'l-Mervezî. Thk. Vasîullah Abbas. 1. Baskı. Hindistan: ed-Dâru's-Selefiyye, 1408.

Mizzî, Yûsuf b. Abdurrahman. Tehzîbü'l-Kemâl fi Esmâi'r-ricâl. Thk. Beşşâr Avvâd. 1. Baskı. Beyrut: er-Risâle, 1400. 
Mogultây b. Kılîc. İkmâlu'l-ikmâl. Thk. Ebû Abdurrahman Âdil b. Muhammed, Ebû Muhammed Usâme b. İbrahim. 1. Baskı. Kahire: Dâru'l-Farûk el-Hadîse, 1422/2001.

Rifâî, Sâlih b. Hâmid. es-Sikat ellezîne duıfû fî ba'dı şuyûhıhim. 2. Baskı. el-Medînetü'lMünevvere: Dâru'l-Hüderî, 1418.

Şeybânî, Abdullah b. Ahmed. el-ilel ve ma'rifetü'r-ricâl. Nşr. Vasiyyullah b. Muhammed Abbas. Beyrut: y.y. 1988.

Uka'ylî, Ebû Ca'fer Muhammed b. A'mr. ed-Duafâu'I-Kebîr. Thk. Abdu'l-Mu'tî Emîn Kalecî. 1. Baskı. Beyrut: Dâru'I-Mektebeti'l-IImiyye. 1404/1984.

Vekîl, Ahmed b. 'Aditıyye. Neslü'l-nibâl bi-mu'cemu'r-ricâl ellezîne turcime lehum fadîletü'şşeyh el-muhaddis Ebû İshâk el-Hunî. 1. Baskı. Kahire: Dâru'l-Muhaddisîn, 2007.

Zebîdî, Muhammed b. Muhammed b. Abdurrezzak. Tâcu'l-'Arûs. Thk. Komisyon. Küvet: Dâru'l-Hidâye, ts.

Zehebî, Muhammed b. Ahmed. Siyer 'Alâmü'n-nübelâ.' Thk. Şuayb el-Arnavût ve Hüseyn el-Esed. 9. Baskı. Beyrut: Müessetü'r-Risâle, 1413/1993.

Zehebî, Muhammed b. Ahmed. el-Kâşif fî ma'rifeti men lehu rivâyetün fi'l-kütübi'l-sitte. Thk. Muhammed Avvâm. 1. Baskı. Cidde: Dâru'l-Kıble li's-Sekâfe'l-İslâmiyye ve Müessetü ulûmi'I-Kur'ân, 1413/1996. 